\title{
Annual variation in condition, respiration and remineralisation of Mytilus edulis L. in the Sound, Denmark
}

\author{
L. Schlüter ${ }^{1,2}$ \& S. B. Josefsen ${ }^{2}$ \\ ${ }^{1}$ National Environmental Research Institute, Division of Marine Ecology and Microbio- \\ logy; Frederiksborgvej 399, P. O. Box 358, DK-4000 Roskilde, Denmark \\ ${ }^{2}$ Water Quality Institute, Agern Allé 11, DK-2970 Horsholm, Denmark*
}

\begin{abstract}
By means of monthly in situ incubations, variations in oxygen uptake, nutrient release and $\mathrm{C} / \mathrm{N}$-ratio were monitored during a period of 14 months of a mussel population (Mytilus edulis L.) located on an exposed beach. A condition index calculated as weight/length ${ }^{3}$ showed that the condition of the mussels was highest in the spring. Specific oxygen uptake and nutrient release had separate maxima, with high oxygen uptake in the spring coinciding with a period of growth, and high nutrient release during summer when the temperature was highest. Oxygen uptake was significantly correlated with both the condition of the mussels and the temperature, while ammonium release was significantly correlated only with the temperature. Except in spring, the oxygen uptake, condition index and $\mathrm{O} / \mathrm{N}$-ratio were low, indicating a poor condition of the mussels. The mussels suffered from suboptimal conditions caused by inadequate food supply and failed to accumulate glycogen reserves essential for the development of mature gametes.
\end{abstract}

\section{INTRODUCTION}

The mussel Mytilus edulis L. is widely distributed in boreal coastal waters. It adapts to survive under extremely varied conditions (Seed, 1969) and tolerates large fluctuations in dry weight (Kautsky, 1982) and body mass composition (Zwaan \& Zandee, 1972; Dare \& Edwards, 1975; Zandee et al., 1980). Growth, condition, reproduction, and metabolic rates of a population are integrated responses of adaptation to the environment, and several factors influence mussels' growth and survival in marginal environments. Supply of food is essential and depends on the horizontal advection, the concentration and vertical mixing of food particles, which are influenced by water velocity and the bottom roughness (Fréchette et al., 1989), but also of importance are the duration of exposure to air (Seed, 1969; Peterson \& Black, 1987), tolerance of desiccation during emersion (Kennedy, 1976) and stress caused by wave action (Harger, 1970). Further, the growth rate and the maximum size of $M$. edulis living in low saline areas $(7 \%$ ) are much lower than in high saline areas $(28 \%$ ), indicating that mussels in low saline areas suffer from a less favourable energy balance (Tedengren \& Kautsky, 1986; Kautsky et al., 1990).

Suboptimal conditions can have a detrimental effect on growth, fecundity and larval

\footnotetext{
* Present address of first author, addressee for all correspondence
} 
survival (Bayne, 1972; Bayne \& Widdows, 1978), and affect metabolism, (Bayne \& Scullard, 1977; Widdows, 1978a), as well as condition and body composition. The aim of this study was to examine the annual fluctuations in metabolism of a mussel population in a poor condition with regard to oxygen uptake, ammonium and phosphate release, in relation to condition and carbon and nitrogen content of the soft parts of the mussels.

\section{MATERIALS AND METHODS}

A scattered population of Mytilus edulis in the Sound, Denmark (Fig. 1) was chosen for the experiment. The population consisted of small thick shelled mussels $(<40 \mathrm{~mm})$ and was located on a beach in the intertidal zone exposed to wave action and large temperature oscillations during emersions. The substrate was coarse sand and gravel. In the subtidal zone the mussel population had a higher density, probably favoured by the continuous water exchange in the Sound. The water reaching the experimental population was therefore to some extent depleted from food particles. In the summer period, growing beds of Zostera marina and Fucus vesiculosus in the subtidal zone reduced the water exchange. Incubations were made every month from February 1991 through March 1992. Mussels in the size range of 29 to $35 \mathrm{~mm}$ were randomly collected from the population, cleaned for epibionts and transferred to one litre plastic chambers. Ten mussels were in each chamber (two replicates, one control without mussels). After 20 minutes of acclimatization, the chambers were closed while under water to avoid air bubbles and incubated in situ for one hour. It was observed that the valves of the mussels were open during the experiment. Stirring was done manually with a magnet every ten minutes. Before and after the incubations, samples in triplicates for oxygen and nutrient

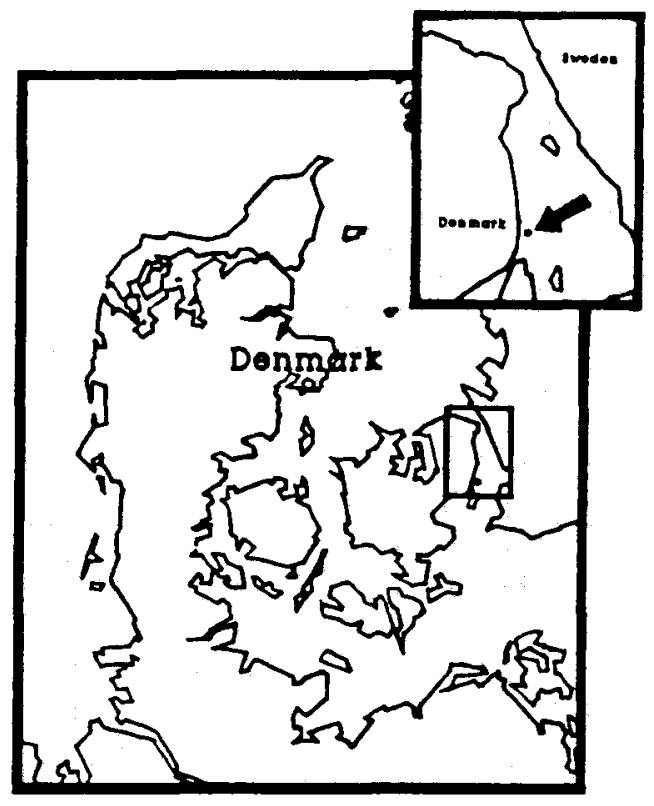

Fig. 1. Location of the study site 
determinations were taken. Ammonium and oxygen reagents were added immediately in the field. Ammonium and oxygen were measured according to Grasshoff \& Johannsen (1972) and Carritt \& Carpenter (1966).

Samples for phosphate analysis were frozen and then measured on an autoanalyser according to the guidelines of Grasshoff et al. (1983). The shell length of the mussels was measured to the nearest $1 / 10 \mathrm{~mm}$. Before the dry weight was determined, the soft parts were dried at $85^{\circ} \mathrm{C}$ for two days and then homogenized to determine the organic nitrogen and carbon content. A Perkin Elmer CHN-elemental Analyser $240 \mathrm{C}$ was used.

Control incubations indicated that planktonic contribution to the fluxes of oxygen and nutrients was low compared to fluxes from mussels (2-23\%). It would have been inaccurate to correct for this contribution, since the mussels change the planktonic composition during the incubation. Consequently, no correction was done.

Growth in shell length in 1991 was estimated from analysis of growth rings on the shells.

A condition index $(C)$ for the mussels in each month was calculated as: $C=W / L^{B}$, where $\mathrm{W}$ is shell free dry weight in $\mathrm{mg}$, and $\mathrm{L}$ is shell length in $\mathrm{cm}$. The value $B$ is reported to vary between 2.44 and 3.31 (Bayne \& Worral, 1980) according to variations in shell dimensions. For the present study a value of 3 was chosen.

Spearman rank correlation coefficients were calculated to assess significance $(*, \mathrm{p}<0.05)$ of the relationships between fluxes and both temperature and condition index.

\section{RESULTS}

- Temperature ranged between $0.7^{\circ} \mathrm{C}$ in the Winter 1991 and $18^{\circ} \mathrm{C}$ in the Summer 1991 (Fig. 2). Salinity fluctuated through the season between 9-18\% (data not shown).

The mussels were always open and filtering in the experiments; except in February (1991), when the valves were almost closed.

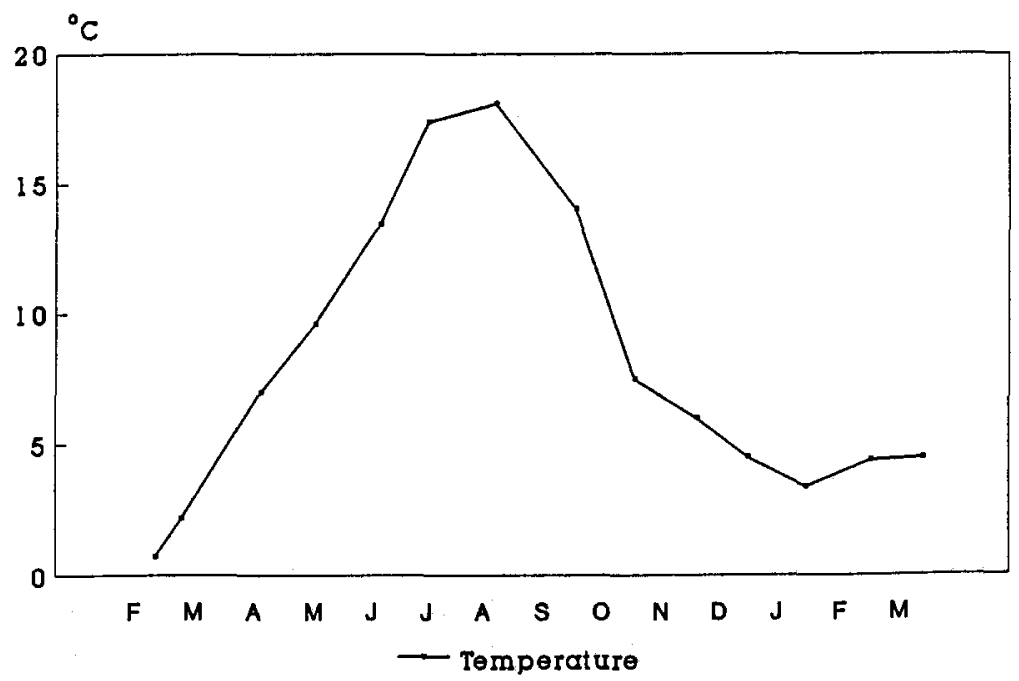

Fig. 2. Annual variation in temperature 


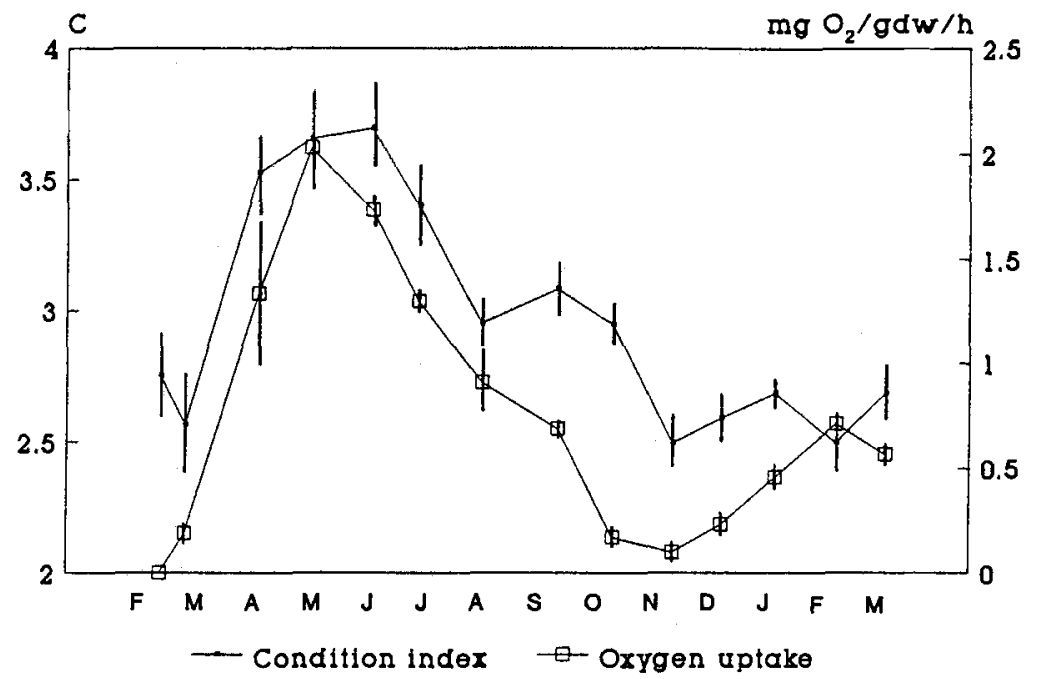

Fig. 3. Annual variation in condition (C) and oxygen uptake for the population. Vertical lines indicate standard errors

The annual growth in shell length of the population varied between individuals, but was estimated to $6 \mathrm{~mm}$ in average in 1991 (data not shown).

The condition of the mussels is expressed by the condition index (C) (Fig. 3), and it increased to a maximum of 3.7 in June and declined to a minimum of 2.5 in February 1992. The increase in spring indicates that the mussels accumulated somatic tissue in this period. The curve shows that the condition of the mussels was at the same level at the start and at the end of the experimental period. Further, the curve shows no obvious sign of spawning (Fig. 3).

The oxygen uptake increased steeply in the spring from a nonmeasurable level in February to a maximum value of $2.0 \mathrm{mg} \mathrm{O} \mathrm{O}_{2} \cdot \mathrm{gdw}^{-1} \cdot \mathrm{h}^{-1}$ in May and declined through summer and autumn (Fig. 3). There was a significant correlation between the oxygen uptake and the condition index $\left(r=0.70^{\circ}\right)$ and the oxygen and temperature $\left(r=0.62^{\circ}\right)$.

The ammonium release increased from a minimum value of $2.0 \mu \mathrm{g} \mathrm{NH}_{4}^{+}-$ $\mathrm{N} \cdot \mathrm{gdw}^{-1} \cdot \mathrm{h}^{-1}$ in February to a maximum value of $44.3 \mu \mathrm{g} \mathrm{NH}_{4}{ }^{+}-\mathrm{N} \cdot \mathrm{gdw}^{-1} \cdot \mathrm{h}^{-1}$ in August, and declined through the autumn (Fig. 4). The winter values in 1992 were higher than in the preceding season, though not statistically significant. Ammonium release was significantly correlated with the temperature $\left(r=0.71^{\circ}\right)$.

Phosphate was mainly released during the summer period and coincided with the period of high ammonium release (Fig. 4) and ranged between 3.0 and $16.3 \mu \mathrm{PO}_{4}{ }^{3-}$. $\mathrm{P} \cdot \mathrm{gdw}^{-1} \cdot \mathrm{h}^{-1}$. The phosphate release did not correlate with the temperature.

The time for maximum oxygen uptake and ammonium release did not coincide (Figs $3,4)$. This is reflected in the fluctuations of the calculated O/N-ratio (by mole) (Fig. 5). A maximum ratio of 132 was attained in early spring, which coincided with the period of growth, reflecting the increase in condition of the mussels. The ratio declined when the condition index decreased during summer and autumn. There seems to be a minor increase in the ratio in the winter, though not statistically significant. 


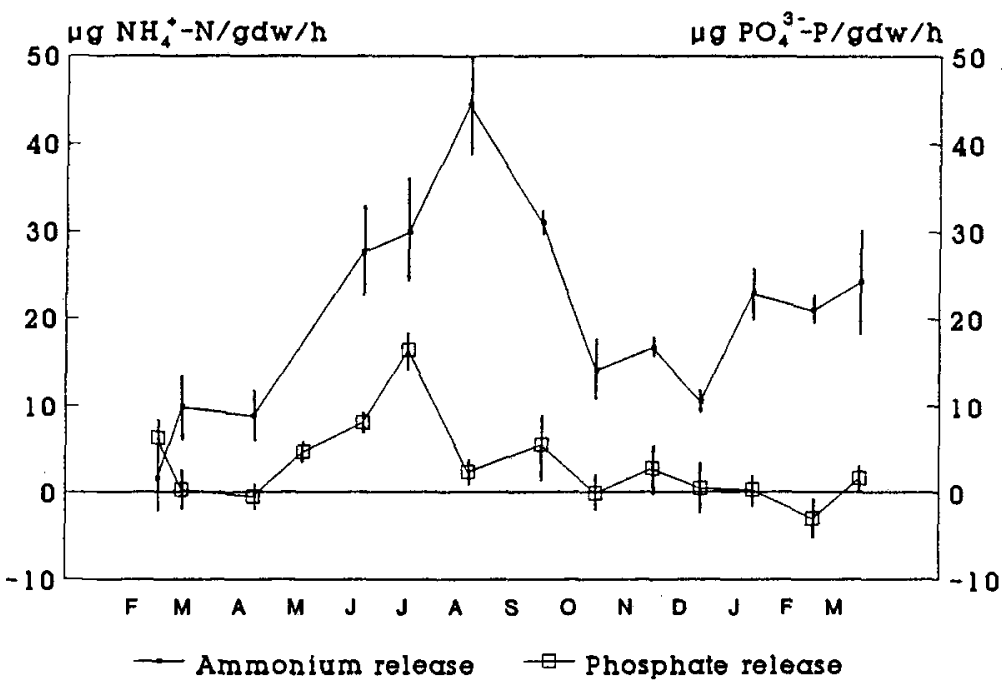

Fig. 4. Annual variation in ammonium and phosphate release for the population. Vertical lines indicate standard errors

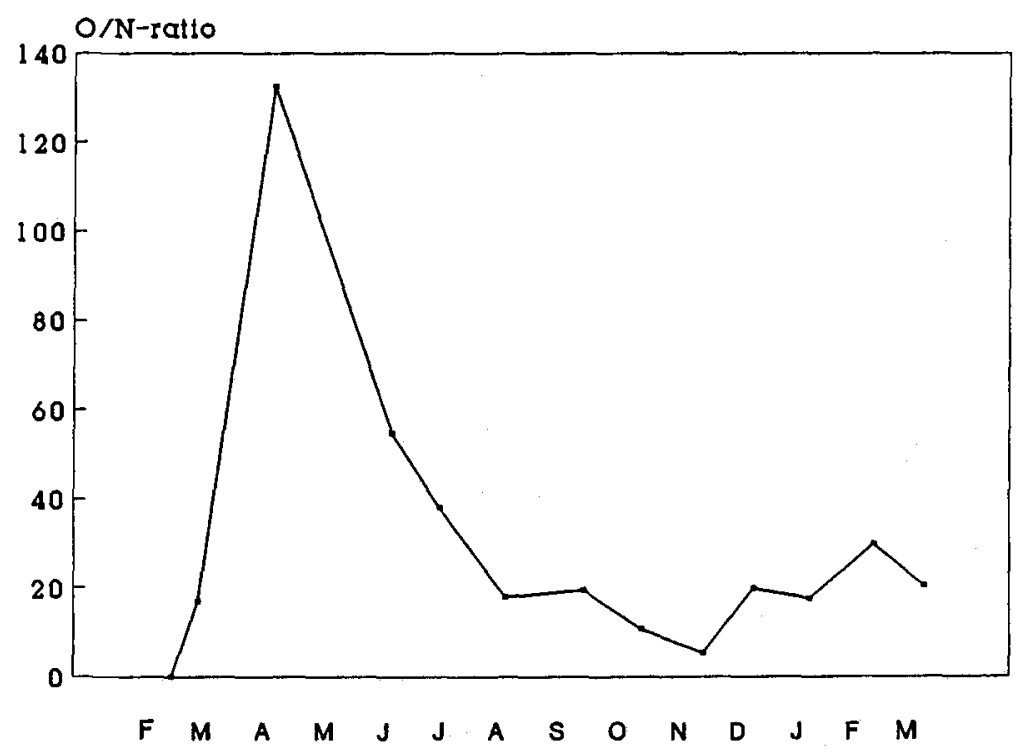

Fig. 5. Annual variation in $\mathrm{O} / \mathrm{N}$-ratio (by mole) for the population

The $\mathrm{C} / \mathrm{N}$-ratio in the soft parts ranged between 3.8 and 4.3 (Fig. 6), which is only slightly above the $\mathrm{C} / \mathrm{N}$-ratio of pure protein (about 3.4 ). The $\mathrm{C} / \mathrm{N}$-ratio was relatively constant through the year, but declined slightly (not significant) in late winter and early spring. 


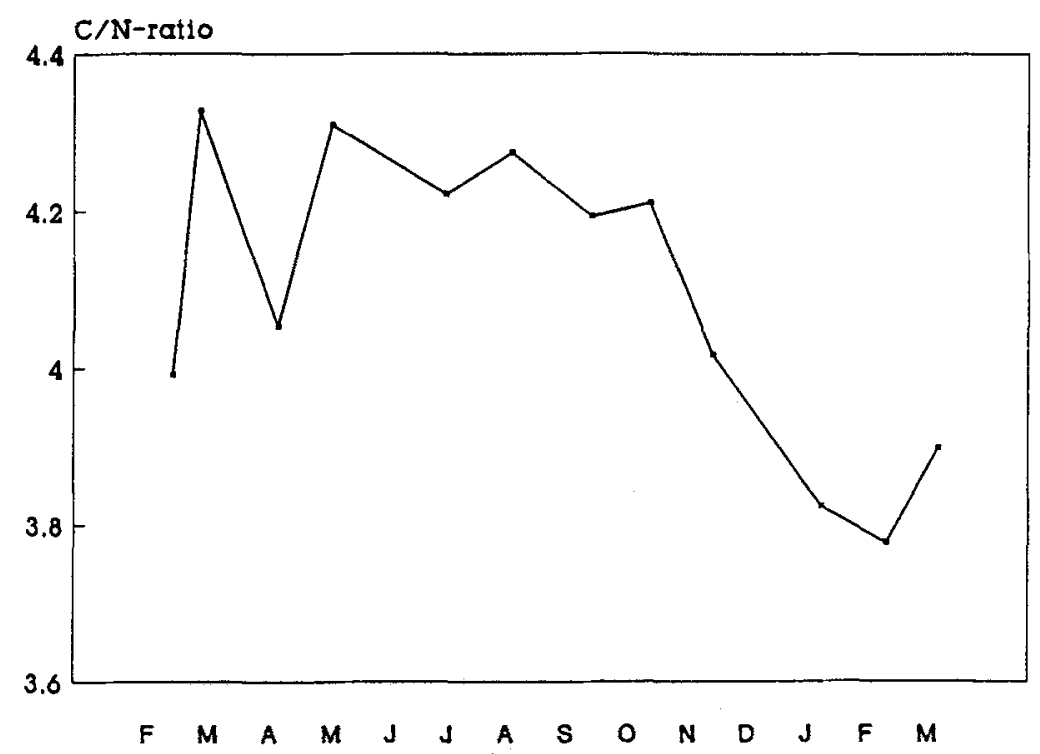

Fig. 6. Annual variation in $\mathrm{C} / \mathrm{N}$-ratio for the population

\section{DISCUSSION}

When interpreting data from incubations, some sources of errors must be considered; the flux rates can be influenced by decline in oxygen tension, accumulation of metabolites and feces, food shortage, as well as enhanced rate of byssus thread production in the incubation chambers, depending on seasonal variation in metabolic activity. In a control experiment, Kautsky \& Wallentinus (1980) found unchanged metabolism in incubated mussels when the oxygen saturation was above $70 \%$, and they demonstrated further that a decline in oxygen saturation, rather than accumulation of metabolites, was responsible for the decline in metabolic activity. Incubation time was kept short (one hour) in this study, and the incubated biomass was low (maximum $1.5 \mathrm{~g} \mathrm{dw} \cdot \mathrm{l}^{-1}$ ). The oxygen saturation never declined below $70 \%$ and the sources of errors in this study are consequently considered of minor importance. Further, Jørgensen et al. (1986) found that oxygen consumption approaches independency of ventilation rate, at rates amounting to $1 / 5$ of the ventilation rate in undisturbed filtering mussels. Since the valves of the mussels in the present study were always open, the ventilation currents are considered to be above the level where the oxygen uptake is influenced, except in the first measurement in February. Food shortage is not likely to have influenced the oxygen uptake due to the short incubation times, since the oxygen consumption is not immediately influenced by the reduction in food availability. Rather, oxygen uptake is an integrated expression of several metabolic processes related to the general level of food supply from the environment.

The condition index in this population was between $2.5-3.7$, which is relatively low compared to the condition of mussel beds in general. Rodhouse et al. (1984) found annual dry weights in $30 \mathrm{~mm}$ mussels in England between 85 and $200 \mathrm{mg}$, which corresponds to 
a condition index of 3.1-7.4. In contrary, condition indexes even lower than those found in the present study are possible. In an aquarium, living mussels measuring $30 \mathrm{~mm}$ were found having dry weights between 30-45 mg (Kautsky, 1982), which corresponds to a condition index between 1.1 and 1.7 .

Spawning is usually triggered by increase in temperature (Bayne, 1975) and is reported to initiate at about $10^{\circ} \mathrm{C}$ [British waters: $9.5-12^{\circ} \mathrm{C}$ (Chipperfield, 1953); Baltic and Kattegat: approximately $10^{\circ} \mathrm{C}$ (Loo, 1991)]. In this study, temperature reached $10^{\circ} \mathrm{C}$ in mid May (Fig. 2), but no obvious sign of spawning can be seen from the condition index curve (Fig. 3). Further, mature gametes were never observed. As the reproductive effort increases with age and size (Bayne et al., 1983; Thompson, 1984), it is likely that the mussels in this study were probably too small and/or in a condition which was too poor for any noticeable spawning. Gabbot \& Bayne (1973) found in laboratory experiments that Mytilus edulis reabsorbed mature gametes, if the mussels were exposed to nutritive and temperature stress at the time of spawning. Whether the poor condition of the mussels in the present study induced a reabsorption and subsequent catabolism of mature gamete tissue is questionable, but it is a possibility. The temperature is not the only factor determining spawning, since gamete production and the succeeding spawning ultimately depend on sufficient nutrient reserves and food availability (Bayne \& Worral, 1980; Newell et al., 1982). The absence of a decline in condition in May (when the temperature reaches $10^{\circ} \mathrm{C}$ ) indicates that spawning is absent or suppressed to a minimum, which can not be detected with the frequency of sampling in this study. Riisgård \& Randløv (1981) observed an increase in shell length under constant or even declining weight of the soft parts. Thus, in the present study, the decline in the condition index in the summer is due to catabolism of body mass or enhancement of the shell growth, or a combination of both, rather than a delayed or repeated period of gamete release.

The increase in shell length in this population, which amounted to approximately $6 \mathrm{~mm}$ in one year (1991), is low for mussels of this size (29-35 mm). Riisgård \& Poulsen (1981) observed a maximum increase in shell length at $11 \mathrm{~mm}$ per month for mussels hung in the water column (initial length of $22-23 \mathrm{~mm}$ ) 'in an eutrophicated Danish fjord, where the mussels probably were close to fully exploiting their potential for growth (Jørgensen, 1990).

Growth experiments, where mussels from the experimental population were transferred to an eutrophicated locality with tidal water flow (same salinity) and placed in the middle of the water column, showed that the mussels in the spring increased the weight of the soft parts, and attained a condition index of $6-8$ in only $1 \frac{1}{2}$ weeks without increasing in shell length (F. Møhlenberg, pers. comm.). When assuming that the noticeable increase in the condition index from March to April (Fig. 3) is due to an increase in dry weight only, and that the increase in length was insignificant in that period, the net growth efficiency $K_{2}$ can be calculated for that period as $K_{2}=G /(G+R)$. $G$ is growth of the soft parts calculated from the condition index, assuming constant length of the shell, and $R$ is the total oxygen uptake from March to April and was estimated by integrating the oxygen uptake between the two monthly measurements, assuming a linear increase in oxygen uptake. Growth (G) was converted to energy equivalents by using the factor $4.9 \mathrm{cal} \cdot \mathrm{mg}^{-1}$ shell free dry weight (Dare \& Edwards, 1975). The oxygen uptake is converted into energy equivalents using a factor of $3.36 \mathrm{cal} \cdot \mathrm{mg} \mathrm{O}_{2}{ }^{-1}$ (Gnaiger \& 
Forstner, 1983). The resulting net growth efficiency $\mathrm{K}_{2}$ was $35 \%$ from March to April. As the possibility of shell growth cannot be totally excluded, this net growth efficiency may be underestimated. For Mytilus edulis $(16-19 \mathrm{~mm}$ ) fed with algae mixed with silt, the maximum net growth efficiency measured in the laboratory was $65 \%$ (Kiørboe et al., 1981). Riisgård \& Poulsen (1981) found, by theoretically calculating oxygen uptake, a maximum net growth efficiency of $73 \%$ for $M$. edulis $(22-23 \mathrm{~mm})$ hung in the water column in an eutrophicated Danish fjord. The maximum net growth efficiency attainable depends on the size of the mussels and tends to decrease with increasing body weight (Jørgensen, 1976). The size of the mussels in the present study is bigger than in the above cited studies, and even though the net growth efficiency of $35 \%$ perhaps is an underestimation, it is still below maximum. The mussels are not exploiting their potential for growth, which indicates less than maximum rates of food assimilation and high relative cost of maintenance, which is an effect of suboptimal environmental conditions. The condition index of the population increased by $37 \%$ in the period with $35 \%$ growth efficiency, and it is likely that this period is vital for the population, since the condition index tends to decline from June and the rest of the year (Fig. 3).

The $\mathrm{C} / \mathrm{N}$-ratio reflects the mutual fluctuations in carbon and nitrogen content in the soft parts of the mussels (Fig. 6). Mussels living under favourable conditions accumulate carbon, i.e. glycogen, through summer to autumn (Seed, 1969; De Zwaan \& Zandee, 1972; Gabbot \& Bayne, 1973), and attain a high content of glycogen relative to protein in autumn. The glycogen is catabolized when food becomes scarce during late autumn and winter (Dare \& Edwards, 1975; Bayne \& Scullard, 1977; Zandee et al., 1980; Hawkins \& Bayne, 1985). In this population, however, both a constant $\mathrm{C} / \mathrm{N}$-ratio and the decline in condition index in summer (Figs 3,6 ) indicate that glycogen is not accumulated to any great extent. This is also obvious when comparing the $\mathrm{C} / \mathrm{N}$-ratios in this study, which ranged between 3.8-4.3, with a C/N-ratio of 8.1 from Mytilus edulis (mean size 5-6 cm) on an intertidal mussel bed in March in Kerteminde, Denmark. Consequently, the amount of stored energy for growth and reproduction is diminutive in the Sound population. The decline in $\mathrm{C} / \mathrm{N}$-ratio during winter/early spring could be interpreted as a higher relative protein content during winter, caused by the exhaustion of this diminutive energy reserve, i.e. glycogen.

The relation between oxygen uptake and dry weight is described by a allometric function (Vahl, 1973; Bayne \& Widdows, 1978; Widdows, 1978a; Famme, 1979; Hamburger et al., 1983). Consequently, the weight specific oxygen uptake rates in this study (Fig. 3) are valid for mussels with a length of about $30 \mathrm{~mm}$ and should only be compared with mussels of that size. The maximum oxygen uptake rate of $2.0 \mathrm{mg} \mathrm{O} \mathrm{O}_{2} \cdot \mathrm{gdw}^{-1} \cdot \mathrm{h}^{-1}$ in May is comparable to a laboratory study with Mytilus edulis, where the maximum oxygen uptake was $1.7 \mathrm{mg} \mathrm{O} \mathrm{O}_{2} \cdot \mathrm{gdw}^{-1} \cdot \mathrm{h}^{-1}\left(20^{\circ} \mathrm{C}\right)$ for $30 \mathrm{~mm}$ mussels (Oertzen, pers. comm. through Kautsky \& Wallentinus, 1980). Unfortunately, no information about the nutritional state of the mussels was reported.

The unmeasurable oxygen uptake in mid February (1991) at $0.7^{\circ} \mathrm{C}$ indicates a very low metabolism. Mussels filter water and take up oxygen even at temperatures below $0^{\circ} \mathrm{C}$, when food is available (Loo, 1992). The spring bloom started in early February 1991 in the Sound (G. Jørgensen, County of Copenhagen, pers. comm.), but the low oxygen uptake and valve closure indicate that the metabolism of the mussels in the present study was low at that time. 
The oxygen uptake was correlated with the condition index and the temperature. However, the curves in Fig. 2 and 3 indicate that the oxygen uptake is better correlated with the condition index than with the temperature. It is likely that the increase in specific oxygen uptake in the spring reflected specific dynamic action (i.e. increase in respiration associated with feeding). Specific dynamic action is largely related to biosynthesis and transport of macromolecules associated with growth (Kiørboe et al., 1985, 1987). Thus, change in growth rate is probably the main factor responsible for the co-variation between weight specific oxygen uptake and condition index in this study. This indicates that, though having a positive effect, the temperature is apparently not determinative for the metabolism of the mussels.

No measurements of excretion of organic $N$ were made, since mussels mainly excrete ammonium (Bayne, 1976; Bayne \& Scullard, 1977; Boucher \& Boucher-Rodoni, 1988). In certain periods, however, excretion of amino acids is considerable, and is reported to range between $0-29 \%$ of the total $\mathrm{N}$ excretion (Bayne \& Scullard, 1977), probably depending on the nutritional state of the mussels (Jørgensen, 1990). The rates of ammonium and phosphate release in this study are comparable to a study on Mytilus edulis (shell length $<40 \mathrm{~mm}$ ), where the nitrogen release rates were between 1 and $76 \mu \mathrm{g}$ $\mathrm{N} \cdot \mathrm{gdw}^{-1} \cdot \mathrm{h}^{-1}\left(\mathrm{NH}_{4}{ }^{+}+\mathrm{NO}_{3}+\mathrm{NO}_{2}\right)$ and phosphate release rates were between zero and $24 \mu \mathrm{g} \mathrm{PO}_{4}{ }^{3-}-\mathrm{P} \cdot \mathrm{gdw}^{-1} \cdot \mathrm{h}^{-1}$, with the highest rates during the summer (Kautsky \& Wallentinus, 1980). The positive relation between temperature and release of nutrients from benthic animals was previously described in the literature (Nixon et al., 1976; Bayne \& Scullard, 1977; Kautsky \& Wallentinus, 1980; Boucher \& Boucher-Rodoni, 1988). In the present study the release of ammonium was significantly correlated with the temperature. However, the ammonium release is not directly dependent on the temperature, but is a consequence of catabolism of proteins, which is related to food quantity and quality. accumulation of energy reserves, growth and the stage in the gametic cycle. The phosphate release is also affected by the factors mentioned in this study (Kuenzler, 1961. investigations of Modiolus demissus). In the studies of Kautsky \& Wallentinus (1980) and Boucher \& Boucher-Rodoni (1988), both the exchange rates of oxygen and nutrients were highest in summer/early autumn, which is in contrast with this study, where the oxygen consumption reaches a maximum already in spring, reflecting the period of growth.

The ratio between oxygen uptake and ammonium release provides an assessment of the nutritional and metabolic state of the mussels (e.g. Bayne \& Scullard, 1977; Widdows, 1978b; Kautsky \& Wallentinus, 1980; Widdows et al., 1984). For mussels with $1 \mathrm{gdw}$, $\mathrm{O} / \mathrm{N}<30$ is generally considered indicative of a stressed condition, since the protein catabolism is high; while $\mathrm{O} / \mathrm{N}>50$ is indicative of nitrogen saving, catabolism of carbohydrates and lipids at a level above maintenance (Widdows, 1978b). The dry weights of the mussels in the present study are approximately $1 / 10$ of $1 \mathrm{gdw}$; consequently, direct comparisons are unwarranted. The high O/N-ratio, however, at 132 in this study in the spring coincides with a high condition index and indicates growth and retaining of nitrogen i.e. synthesis of protein. The $\mathrm{O} / \mathrm{N}$-ratios are below 20 from August to January, indicating a relative high nitrogen release and a generally poor condition. During winter there seems to be an increase, though not significant, in oxygen uptake, ammonium release and the $\mathrm{O} / \mathrm{N}$-ratio. These increments could be a response to a mild winter in 1991/92 with higher temperature and a relatively high activity of benthic and pelagic organisms. The $\mathrm{O} / \mathrm{N}$ variations through the year are not reflected in similar 
variations in $\mathrm{C} / \mathrm{N}$-ratios (Figs 5, 6). This indicates that the biochemical composition of the food metabolized by the mussels deviates from the biochemical composition of the soft parts of the mussels.

An expression for the yearly "inorganic excretion balance" between C:N:P is obtained by integrating the total oxygen uptake and ammonium and phosphate release through 12 months and converting oxygen uptake to carbon respired, assuming a respiratory quotient of 1 . The resulting $C: N: P$ ratio is $395: 17: 1$. Comparison with the Redfield ratio of 106:16:1 (Redfield, 1958) reveals that $N$ and $P$ are released in the same ratio as ingested, but at a reduced level compared to the metabolism of carbon. The explanation for this discrepancy could be a higher relative content of $N$ and $P$ in excreted organic molecules (i.e. amino acids), feces and produced byssus threads or a higher carbon content in the food than in the Redfield ratio. However, this is speculative, since no samples were taken for verification. Nevertheless, the consistence in the ratio between $\mathrm{N}$ and $\mathrm{P}$ ingested and released indicates a close relation between the catabolism of organic $\mathrm{N}$ and $\mathrm{P}$ in the mussels.

The previously described example, where mussels from this population were transplanted to an area with a horizontal transport of food particles, which resulted in an immense increase in the condition index of the mussels, suggests that this population is suffering from some kind of disadvantage. The condition of the mussels declines during the summer, directly as a consequence of a reduced or negative growth in dry weight, combined with an increase in shell length. Even though the availability of reliable measurements of food supply to the experimental population is lacking, it can be concluded that the food supply is limiting the growth and the condition of the mussels. Assuming a negative growth in the summer the metabolism must have been turned towards a higher dependence on body reserves. A high ammonium release together with a decline in the oxygen uptake (low $\mathrm{O} / \mathrm{N}$ ), indicates that the mussels to a great extent metabolized proteins. Several factors are probably influencing the food availability, but the most obvious is the limited horizontal advection of food particles to the population, partly due to restricted water exchange caused by beds of Fucus vesiculosus and Zostera marina, or depletion of food particles from the water by subtidal communities of Mytilus edulis surrounding the population in the experimental area. The restricted supply of food during the summer is probably the reason for the absence of glycogen reserves, which according to the constant $\mathrm{C} / \mathrm{N}$-ratio, fail to accumulate during late summer/early fall. Instead the condition declines during autumn, as do the oxygen uptake and ammonium release, both as a consequence of a decline in food concentration and temperature. The absence of the accumulation of glycogen reserves is detrimental, since the initiation and development of gonads are relying on glycogen reserves (Gabbot \& Bayne, 1973; Bayne et al., 1982), which also indicates that gamete production is inhibited in this population. Hence, the population must be recruited from subtidal populations.

Acknowledgements. The authors wish to thank F. Møhlenberg and O. Geertz-Hansen for valuable advice and discussions during the project, F. Møhlenberg and T. Gissel Nielsen for critical reading of the manuscript, and $\mathrm{H}$. Ferdinand and P. Kofoed for their technical assistance. 


\section{LITERATURE CITED}

Bayne, B. L., 1972. Some effects of stress in the adult on the larval development of Mytilus edulis.Nature, Lond. 237, 459.

Bayne, B. L., 1975. Reproduction in bivalve molluscs under environmental stress. In: Physiological ecology of estuarine organisms. Ed. by F. J. Vernberg. University of South Carolina Press, Columbia, South Carolina, 259-277.

Bayne, B. L. (Ed.) 1976. Marine mussels. Their ecology and physiology. Cambridge University Press, Cambridge, 506 pp.

Bayne, B. L. \& Scullard, C., 1977. Rates of nitrogen excretion by species of mytilus (Bivalvia: Mollusca). - J. mar. biol. Ass. U. K. 57, 355-369.

Bayne, B. L. \& Widdows, J., 1978. The physiology of two populations of Mytilus edulis L. - Oecologia $37,137-162$.

Bayne, B. 'L. \& Worral, C. M., 1980. Growth and production of mussels Mytilus edulis from two popuations. - Mar. Ecol. Prog. Ser. 3, 317-328.

Bayne, B. L., Bubel, A., Gabbot, P. A., Livingstone, D. R., Lowe D. M. \& Moore, M. N., 1982. Glycogen utilisation and gametogenesis in Mytilus edulis L. - Mar. Biol. Lett. 3, 89-105.

Bayne, B. L., Salkeld, P. N. \& Worral, C. M., 1983. Reproductive effort and value in different populations of the marine mussel, Mytilus edulis L. - Oecologia 59, 18-26.

Boucher, G. \& Boucher-Rodoni, R., 1988. In situ measurements of respiratory metabolism and nitrogen fluxes at the interface of oyster beds. - Mar. Ecol. Prog. Ser. 44, 229-238.

Carrit, D. E. \& Carpenter, J. H., 1966. Comparison and evaluation of currently employed modifications of the Winkler method for determining dissolved oxygen in seawater; a NASCO report. - J. mar. Res. 24, 286-318.

Chipperfield, P. N. J., 1953. Observations on the breeding and settlement of Mytilus edulis in British Waters. - J. mar. biol. Ass. U. K. 32, 449-476.

Dare, P. J. \& Edwards, D. B., 1975. Seasonal changes in flesh weight and biochemical composition of mussels (Mytilus edulis L.) in the Conway Estuary, North Wales. - J. exp. mar. Biol. Ecol. 18, 89-97.

Famme, P., 1979. Oxygen-dependence of the respiration by the mussel Mytilus edulis L. as a function of size. - Comp. Biochem. Physiol. 67A, 171-174.

Fréchette, M., Butman, C. A. \& Geyer, W. R., 1989. The importance of boundary-layer flows in supplying phytoplankton to the benthic suspension feeder, Mytilus edulis L. - Limnol. Oceanogr. 34, 19-36.

Gabbot, P. A. \& Bayne, B. L., 1973. Biochemical effects of temperature and nutritive stress on Mytilus edulis L. - J. mar. biol. Ass. U. K. 53, 269-286.

Gnaiger, E. \& Forstner, H. (Eds), 1983. Polarographic oxygen sensors. Springer, Berlin, 370 pp.

Grasshoff, K. \& Johannsen, H., 1972. A new sensitive and direct method for the automatic determination of ammonia in sea water. - J. Cons. int. Explor. Mer. 34, 516-521.

Grasshoff, K., Ehrhardt, M. \& Kremling, K. (Eds), 1983. Methods of seawater analysis. Verl. Chemie, Weinheim, $419 \mathrm{pp}$.

Hamburger, K., Møhlenberg, F., Randløv, A. \& Riisgård, H. U., 1983. Size, oxygen consumption and growth in the mussel Mytilus edulis, - Mar. Biol. 73, 303-306.

Hawkins, A. J. S. \& Bayne, B. L., 1985. Seasonal variation in the relative utilization of carbon and nitrogen by the mussel Mytilus edulis: budgets, conversion efficiencies and maintenance requirements. - Mar. Ecol. Prog. Ser. 25, 181-188.

Harger, J. R. E., 1970. The effect of wave impact on some aspects of the biology of sea mussels. Veliger $124,401-414$.

Jørgensen, C. B., 1976. Growth efficiencies and factors controlling size in some mytilid bivalves, especially Mytilus edulis L.: Review and interpretation. - Ophelia 15, 175-192.

Jørgensen, C. B., 1990. Bivalve filter feeding: Hydrodynamics, bioenergetics, physiology and ecology. Olsen \& Olsen, Fredensborg, Denmark, $140 \mathrm{pp}$.

Jørgensen, C. B., Møhlenberg, F. \& Sten-Knudsen, O., 1986. Nature of relation between ventilation and oxygen consumption in filter feeders. - Mar. Ecol. Prog. Ser. 29, 73-88.

Kautsky, N., 1982. Growth and size structure in a Baltic Mytilus edulis population. - Mar. Biol. 68, $117-133$.

Kautsky, N. \& Wallentinus, I., 1980. Nutrient release form a Baltic Mytilus-red algal community and its role in benthic and pelagic productivity. - Ophelia (Suppl.) 1, 17-30. 
Kautsky, N., Johannesson, K. \& Tedengren, M., 1990. Genotypic and phenotypic differences between Baltic and North Sea populations of Mytilus edulis evaluated through reciprocal transplantations. I. Growth and morphology. - Mar. Ecol. Prog. Ser. 59, 203-210.

Kennedy, V. S., 1976. Desiccation, higher temperature and upper intertidal limits of three species of sea mussels (Mollusca: Bivalvia) in New Zealand. - Mar. Biol. 35, 127-137.

Kiørboe, T., Møhlenberg, F. \& Nøhr, O., 1981. Effect of suspended bottom material on growth and energetics in Mytilus edulis. - Mar. Biol. 61, 283-288.

Kiørboe, T., Møhlenberg, F. \& Hamburger, K., 1985. Bioenergetics of the planktonic copepod Acartia tonsa: relation between feeding, egg production and respiration, and composition of specific dynamic action. - Mar. Ecol. Prog. Ser. 26, 85-97.

Kiørboe, T., Munk, P. \& Richardson, K., 1987. Respiration and growth of larval herring Clupea harengus: relation between specific dynamic action and growth efficiency. - Mar. Ecol. Prog. Ser. 40, 1-10.

Kuenzler, E. J., 1961. Phosphorus budget of a mussel population. - Limnol. Oceanogr. 6, 400-415.

Loo, L.-O., 1991. Benthic-pelagic coupling in a boreal marine ecosystem. Ph. D. Thesis, Univ. Göteborg, $101 \mathrm{pp}$.

Loo, L.-O., 1992. Ingestion rates, assimilation, respiration and growth of Mytilus edulis L. at low temperatures. - Ophelia 35, 123-130.

Newell, R. I. E., Hilbish, T. J., Koehn, R. K. \& Newell, C. J., 1982. Temporal variation in the reproductive cycle of Mytilus edulis $\mathrm{L}$. (Bivalvia, Mytilidae) from localities on the East Coast of the United States. - Biol. Bull. mar. biol. Lab., Woods Hole, 162, 299-310.

Nixon, S. W., Oviatt, C. V. \& Hale, S. S., 1976. Nitrogen regeneration and the metabolism of coastal marine bottom communities. In: The role of terrestrial and aquatic organisms in decomposition processes. Ed. by J. Anderson \& A. Macfadyen, Blackwell, London, 269-283.

Peterson, C. H. \& Black, R., 1987. Resource depletion by active suspension feeders on tidal flats: influence of local and tidal elevation. - Limnol. Oceanogr. 32, 143-166.

Redfield، A. C., 1958. The biological control of the chemical factors in the environment. - Am. Scient. $46,205-211$.

Riisgård, H. U. \& Poulsen, E., 1981. Growth of Mytilus edulis in net bags transferred to different localities in an eutrophicated Danish Fjord. - Mar. Pollut. Bull. 12, 272-276.

Riisgård, H. U. \& Randløv, A., 1981. Energy budgets, growth and filtration rates in Mytilus edulis at different algal concentrations. - Mar. Biol. 61, 227-234.

Rodhouse, P. G., Roden, C. M., Burnell, G. M., Hensey, M. P., McMahon, T., Ottway, B. \& Ryan, T. H., 1984. Food resource, gametogenesis and growth of Mytilus edulis on the shore end in suspended culture: Killary Harbour, Ireland. - J. mar. biol. Ass. U. K. 64, 513-529.

Seed, R., 1969. The ecology of Mytilus edulis L. (Lamellibranchiata) on exposed rocky shores. II. Growth and mortality. - Oecologia 3, 317-350.

Tedengren, M. \& Kautsky, N, 1986. Comparative study of the physiology and its probable effect on the size in blue mussels (Mytilus edulus L.) from the North Sea and the Northern Baltic Proper. Ophelia 25, 147-155.

Thompson, R. J., 1984. Production, reproductive effort, reproductive value and reproductive cost in a population of the blue mussel Mytilus edulis from a subarctic environment. - Mar. Ecol. Prog. Ser. 16, 249-257.

Vahl, O., 1973. Pumping and oxygen consumption rates of Mytilus edulis. L. of different sizes. Ophelia 12, 45-52.

Widdows, J., 1978a, Combined effects of body size, food concentration and season on the physiology of Mytilus edulis, - J. mar. biol. Ass. U.K. 58, 109-124.

Widdows, J.; 1978b. Physiological indices of stress in Mytilus edulis - J. mar. biol. Ass. U. K. 58, 125-142.

Widdows, J., Donkin, P., Salkeld, P. N., Cleary; J. J., Lowe, D. M., Evans, S. V. \& Thompson, P. E., 1984. Relative importance of environmental factors in determining physiological differences between two populations of mussels Mytilus edulis. - Mar. Ecol. Prog. Ser. 17, 33-47.

Zandee, D. I., Kluytmans, J. H. \& Zurburg, W., 1980. Seasonal variations in biochemical composition of Mytilus edulis with reference to energy metabolism and gametogenesis. - Neth. J. Sea Res. 14, $1-29$.

Zwaan, A. de \& Zandee, D. I., 1972. Body distribution and seasonal changes in the glycogen content of the common sea mussel Mytilus edulis. - Comp. Biochem. Physiol. 43A, 53-58. 